\title{
Effectiveness of Lavender Aromatherapy on Perineum Pain Intensity among Postpartum Mothers with Normal Labor: A Literature Review
}

Nunung Nurhayati, Nifa Septia Nuraeni, Dewi Marfuah, and Suci Noor H

Vocational Education Program, Nursing Studies Program, STIKep PPNI Jawa Barat, Bandung, Indonesia

\section{ORCID:}

Nunung Nurhayati: https://orcid.org/0000-0001-7778-0971

\section{Abstract}

Perineal pain is one of the problems for postpartum mothers. The intensity of the pain depends on the degree of rupture and parity factors. Perineal pain that is not treated will cause discomfort and mothers being afraid to mobilize early and can also cause perineal infections and bleeding. Perineal pain can be overcome using lavender aromatherapy, as linalool and linalyl acetate in lavender has an analgesic effect. This research conducts a literature review about lavender aromatherapy's effectiveness on the intensity of perineal pain in the postpartum women. The research method used is a literature review with a total of five articles included. One article was obtained from PubMed with the keywords 'lavender oil aromatherapy' AND 'perineal pain' AND 'postpartum'. The other four articles were found on Google Scholar with the keywords 'Aromatherapy lavender', 'perineal pain', 'postpartum'. The inclusion criteria of selected articles are respondents in the study were postpartum mothers with perineal trauma, interventions were given lavender aromatherapy, and the outcome is perineal pain. The results showed that lavender aromatherapy effectively reduced perineal pain in postpartum mothers who experienced trauma in perineum. It is expected that practitioners can apply aromatherapy interventions in reducing perineal pain.

Keywords: Lavender aromatherapy, perineal pain, postpartum, literature review
Selection and Peer-review under the responsibility of the IVCN Conference Committee.

\section{Introduction}

The majority of postpartum mothers suffer from perineum pain, at least in the first few days after birth. Although women experience pain during childbirth, postpartum pain usually occurs as an unwanted attack. As a result of maternal pain, experienced postpartum discomfort disrupted early breastfeeding initiation for less than 1 hour, and the mother was reluctant to perform an early mobilization. Pain also can cause difficulty in caring for the baby, disrupting the early breastfeeding initiation process's bonding, 
and potentially disrupting the mother's transition [1]. The effect of perineum pain is that it often makes the mother postpartum very uncomfortable (51\%), experiencing the fear of doing early mobilization (40\%) that can result in delays in uterine involution (10\%), an irregular production of lochia (13\%), postpartum bleeding (6\%) and infection (5\%). Pain also can make mothers sit comfortably, which can have an adverse effect on the mother's desire to breastfeed (9\%). Perineum pain can affect women's well-being physically, psychologically, and socially [2]

Treatment of perineum pain exists pharmacologically and non-pharmacologically. The use of pharmacological methods is a pain killer using chemical drugs by administering analgesics and anesthesia. Still, pharmacological method use can cause side effects for the body, such as drowsiness, nausea, and long-term benefit that can damage the kidney and liver and cause heart disease. Non-pharmacological methods are a natural pain relief method without using chemical drugs such as aromatherapy [3].

Aromatherapy is a type of alternative treatment that uses liquid ingredients with no have side effects. Aromatherapy is known as essential oils and other aromatic compounds from plants that aim to affect a person's mood or health, reduce stress, calm the mind, excite, and increase concentration. Aromatherapy can be used as lavender, lemon, jasmine, orange, peppermint, rosemary, and other aromatherapy [4].

Currently, lavender has been developed all over the world. This beautiful and small purple flowering plant has properties that are very beneficial to humans. Lavender aromatherapy oil is known as sedative oil, which occurs due to the oil's coumarin compound [5]. Theoretically, lavender aromatherapy works affecting not only physical but emotional levels. The lavender oil content, consisting of linalool, linalyl acetate, can relieve pain [6].

Even though numerous studies were conducted to measure the effectiveness of aromatherapy intervention, the result still inconsistent. Therefore, a literature review to summarize some articles are needed. This literature review aims to explain lavender aromatherapy's effectiveness on the intensity of perineal pain in the postpartum woman.

\section{Methods}

This scientific paper's writing is a literature review of lavender aromatherapy's effectiveness in postpartum mothers' perineum pain intensity with normal labor, using a search strategy through Google Scholar and Pubmed databases. The keyword in English is the combination of lavender oil aromatherapy AND perineal pain AND postpartum. Obtained from Scholar as many as 56 journals, from 56 articles published, only five 
articles meet the inclusion criteria. One article was published in 2016, 2 articles in 2017, and one last article in 2019. From the results of searches conducted through PubMed obtained 2 articles with a combination of keywords lavender oil aromatherapy AND perineal pain AND postpartum, articles published over 2015, full text, and free full text, so that only 1 article obtained, the article was published in 2017. The researcher did not obtain a quality study assessment.

\section{Result}

As many as 5 articles acquired discuss whether lavender aromatherapy reduces pain intensity on the perineum postpartum with 149 respondents. Four articles were conducted in Indonesia and one article in Iran. The aromatherapy intervention was given after 2 hours postpartum with 3 to 5 drops through inhalation technique.

The first article by Windayani Wiwin, 2016 [7], conducted research with 28 respondents and recruited through consecutive sampling. This research is a quasi-experiment designed one group pre and post-test. Respondents were given intervention after 2 hours after stitching the perineum. After filling out the questionnaire, respondents were given lavender aromatherapy inhalation interventions within the 10th, 30th, 60th minute. Aromatherapy is administered for 10 minutes. Then posttest was done along with the observation of the postpartum period in 2 hours, and the instrument used to measure the pain scale of respondents was a visual analog scale so that the results showed a meaningful difference between the level of perineum pain before and after aromatherapy inhalation lavender $\mathrm{p}<0.05$.

The second article was published in 2017. This research was conducted at Semarang City Hospital by Angki Bagus Pramudi dan Ending Supriyanti [8]. The sample in this study was a postpartum mother of 5 people with purposive sampling techniques. The research design used is case study research with One Group Pretest-Posttest Design. Respondents were given aromatherapy interventions performed by dripping lavender oil extract on cotton or handkerchief as much as 3 - 5 drops, then close the cotton or handkerchief given the lavender oil on the nose. Then the patient was advised to inhale it slowly for 15 minutes. This is done twice or two days of administration with different days or hours of administration to validate the effect of lavender aromatherapy on pain in normal postpartum mothers. The instrument used to measure pain intensity is numeric rating scale doubles (NRS). The research shows that after the lavender aromatherapy inhalation, the pain intensity was decreased from 5.4 to 2.8 . 
The third article was published in 2017. The research was conducted by Umaroh and Melyana Nurul Widyawati Kajen Pekalongan in public health [9]. Thirty respondents are divided into 15 , the intervention group and the control group of 15 , recruiting samples using an accidental sampling technique. This research used pre and experimental research post-control group design. The intervention applied inhalation lavender aromatherapy for 30 minutes on the intervention group while the control group gets standard care. For measuring the intensity of pain, the instrument used is the numeric rating scale (NRS). This study showed some influence lavender aromatherapy to pain on the perineum postpartum with p-value $0,000<0,05$.

The fourth article was published in 2017. The fourth article was conducted by Farideh Vaziri, Mahsa Shiravani, Fatemeh Sadat Najib, Saeedeh Pourahmad, Alireza Salehi, Zahra Yazdanpanahi at Shiraz University of Medical Sciences, Iran [10]. This study's sample was 56 people with normal childbirth divided into two groups, namely 29 intervention groups and 27 people into the control group with convenience sampling techniques. The research design used is experimental with pre and post-control group design. Intervention is carried out by means of lavender essential oil dripped as much as five drops on cotton, then placed $15-20 \mathrm{~cm}$ from the patient's nose and inhaled for 10-15 minutes. An hour later, the patient was evaluated. The instrument used to measure the pain scale was a visual analog scale (VAS). The results of this study showed that there was no significant difference in pain after evaluation. Still, after the evaluation the next morning, there was a significant difference between the two groups in perineum pain $(P=0.004, P<0.001)$.

The fifth article was published in 2019, conducted by Anita Indra Afriani, Deny Rahmawati, at Puskesmas Bonang Demak [11]. This study sample was 30 divided into two groups, namely 15 intervention groups and 15 control groups, sample selection using total sampling techniques. This research is quantitative and uses a quasi-experimental design with two group pretest-posttest with control design. The article does not explain how the process of administering lavender aromatherapy intervention in respondents, but in the article, it is written that the instrument used to measure pain intensity is to use a numeric rating scale (NRS). This study showed a decrease in perineum pain between before and after, which was 1.0, where before the aroma struck lavender, the average value was 3.2. The average cost after the aromatherapy lavender was 2.2 with a Wilcoxon $p$-value is $p=0.001$, indicated having a significantly different pain intensity between groups. 


\section{Discussion}

Pain is one of the symptoms that is often complained about in the mother after giving birth. Postpartum discomfort in the form of pain can be caused by spontaneous and episiotomy. The experience of pain felt by the postpartum mother will depend on the degree of perineum wound experienced. Previous research [2] showed that of the 59 respondents who experienced laceration complained of mild pain $66.1 \%$, moderate pain $23.7 \%$, and severe pain $6 \%$, while based on other research [12] wrote that 18 respondents who underwent an episiotomy as 13 respondents (72.2\%) severe pain, as many as 5 respondents (27.8\%) complain of moderate pain.

The results showed that reducing perineum pain in postpartum mothers can be done by providing lavender aromatherapy. A total of 5 articles discussing lavender aromatherapy therapy can decrease the intensity of pain. The study results in article 1 show a significant difference between perineum pain level before and after aromatherapy inhalation lavender $\mathrm{p}<0.05$. The study results in article 2 showed that before aromatherapy, lavender inhalation averaged pain intensity on a scale of 5.4. At the same time, after aromatherapy, lavender pain intensity decreased by an average scale of 2.8. The study results in article 3 show lavender aromatherapy on perineum pain in postpartum mothers with $p$ a value of $0,000<0.05$. In article 4 of the study showing after intervention and evaluation, there was a significant difference between the two groups in perineum pain with $(\mathrm{P}=0.004, \mathrm{P}<0.001)$, and in the results of the study, article 5 showed there was a decrease in perineum pain between before and after, which was 1.0 where before the aroma struck lavender the average value was 3.2 and the average value after the aromatherapy lavender was 2.2. The normality test obtained abnormal data distribution. Using the Wilcoxon sign test obtained a value of $p=0.001$ because the value $p<0.05$ shows a difference in pain before and after being given lavender aromatherapy.

The findings seem similar to several studies conducted on postpartum mothers with aromatherapy that lavender can decrease pain intensity. Theoretically, aromatherapy lavender works affecting not only physical but emotional levels. The lavender oil content, consisting of linalool acetate that can relieve pain [6]. Intervention can be given in the lavender aromatherapy inhalation. Another study [13] explained that when lavender particles inhaled and enter through the nose, then received by receptors nerves as opposed to and then interpreted as pleasing a pleasant odor, and stimulate the sensory smell then influence in the limbic system as a center a person emotion, relax and eventually the reduced pain. When aromatherapy stimulates the hypothalamus hypophyses to 
secretes the hormone endorphin. Endorphins may make it cause quiet, relaxation, and happiness [14].

\section{Conclusion}

Based on the various the test which has been done, it can be concluded that the lavender aromatherapy proves to provide a positive effect to lower the perineum on the intensity of pain. The lavender aromatherapy techniques effectively given in 2 hours postpartum utilizing inhalation due to the impact of lavender aromatherapy stimulates the hypothalamus to eject hormone endorphin known endorphin.

\section{References}

[1] Nugroho, T. (2014). Book Parturition Teaching Obstetrics Care (vol. 3). Yogyakarta: Nuha Medika.

[2] Mulati, T. S. (2016). Bentuk Dan Derajat Luka Perineum Ibu Nifas Di Wilayah Kabupaten Klaten. Jurnal Kebidanan dan Kesehatan Tradisional, vol. 1, issue 2. Hal:1-9.

[3] Judha, S. and Fuziah, A. (2012). The Theory of Pain \& Pain Childbirth. Yogyakarta: Nuha Medika.

[4] Widyarto, A. N. (2015). Citrus Nobilis Lour (Citrus Nobilis Lour) Antibacterial Activity Test Against Staphylococcus aureus and Escherichia coli. (Fakultas Farmasi Universitas Muhammadiyah Surakarta, 2015).

[5] Khasani, I. N. A. (2013). Aromatherapy Effect on Pain in Patients Post Surgery Sektio Caesarea in Hospital Kajen Pekalongan District. Retrieved from www.e-skripsi. stikesmuhpkj.ac.id.

[6] Nuraini, D. N. (2014). Various Benefits of Flowers for Health. Yogyakarta: Gava Media.

[7] Windayani, W. (2016). Aromatherapy of Lavender may Lower the Intensity of Perineum Pain in Postpartum Mothers. Poltekkes Kemenkes Bandung. Jurnal Ners Dan Kebidanan Indonesia. Vol. 4, issue 3. Hal: 123-128.

[8] Pambudi, A. B. and Supriyanti, E. (2017). Effect of Lavender Aromatherapy on Decreased Pain Intensity in Normal Postpartum Patients at Semarang City Hospital. Akademi Keperawatan Widya Husada Semarang. Jurnal Manajemen Asuhan Keperawatan, vol. 1, issue 1. Hal: 1-9. 
[9] Umaroh, W. T. and Widyawati, M. N. (2017). The Effect of Lavender Aromatherapy to Perineum Wound Pain Post Partum. Poltekkes Kemenkes Semarang. Jurnal Ners dan Kebidanan Indonesia. Vol. 2, issue 1. Hal: 16-20.

[10] Vaziri, F., et al. (2017). Effect of Lavender Oil Aroma in the Early Hours of Postpartum Period on Maternal Pains, Fatigue, and Mood: A Randomized Clinical Trial. International Journal of Preventive Medicine. Vol. 8, issue 8, p. 29.

[11] Afriani, A. I. and Rahmawati, D. (2019). The Effect of Lavender Aromatherapy on Decreasing of Perineum Paint Pain in Breast Mother. Media Keperawatan Indonesia, vol. 2, issue 1. Hal: 15-20.

[12] Rahayuningsih, F. B., et al. (2015). Pengetahuan Ibu Hamil Trimester III Tentang Perawatan Nifas Dan Bayi Baru Lahir. Presented at Seminar Nasional Fakultas IImu Kesehatan, vol. 2460, p. 4143. Surakarta-Indonesia, 11 Juni 2015, Publisher: Universitas Muhammadiyah Surakarta.

[13] Kristanti, E. E. (2010). Effect of Lavender Aromatherapy on Decreased Degrees of Anxiety in the Elderly at St Yoseph Kediri Wredha Orphanage. J. Stikes RS Baptis Kediri, vol. 3, issue 2, pp. 94- 100.

[14] Pratiwi, R., Sabar, E., \& Widiasih, R. (2012). Decreased Pain Intensity Due to Post Section Caesarea Wounds after Breathing Relaxation Techniques using Lavender Aromatherapy at Al Islam Hospital Bandung. Students e-journals, vol. 1, issue 1, pp. $1-15$. 